Jurnal Akuntansi Bisnis, Vol. 19, No. 2, September 2021

ISSN 1412-775X (media cetak) | 2541-5204 (media online)

\title{
Pengaruh Struktur Kepemilikan, Ukuran Komite Audit, Ukuran Dewan Komisaris dan Jenis Kepemilikan Terhadap Manajemen Laba
}

\author{
Alma Nadya Pramitha \\ Universitas Katolik Soegijapranata \\ Corresponding author email: 17g10082@student.unika.ac.id
}

\begin{abstract}
The purpose of this study is to re-examine the determinants of earnings management using companies listed on the Indonesia Stock Exchange. More specifically, this study examines the effect of ownership structure, size of the board of commissioners, and size of the audit committee on earnings management. This research is different from previous research conducted in the Indonesian capital market because it adds a new variable, namely the type of ownership. The sample was taken from the period 2015-2019 with purposive sampling method. A total of 1833 company observations could be collected during the study period. However, 513 observations must be eliminated to meet assumptions underlying multiple regression. The study included three control variables to control for differences in the characteristics of the company sample, namely company size, leverage, and profitability. The results of the regression analysis show that: 1) Institutional ownership has no significant effect on earnings management. 2) Managerial ownership has no significant effect on earnings management. 3) size of Audit Committee has no significant effect on earnings management. 4) Board of Commissioners size has no significant effect on earnings management. 5) Type of Ownership has a significant positive effect on earnings management. In addition, of the three control variables used, there are two that affect earnings management, namely firm size and profitability. Leverage has no significant effect on earnings management.
\end{abstract}

\section{Keywords: Earnings management, managerial ownership, Board of Commissioners,} audit committee, ownership structure.

\begin{abstract}
Abstrak
Penelitian ini bertujuan untuk menguji kembali determinan manajemen laba dengan menggunakan perusahaan yang terdaftar di Bursa Efek Indonesia. Lebih spesifik, penelitian ini menguji pengaruh struktur kepemilikan, ukuran dewan komisaris, dan ukuran komite audit terhadap manajemen laba. Penelitian ini berbeda dengan penelitian sebelumnya dilakukan di pasar modal Indonesia karena menambah satu variabel baru yaitu jenis kepemilikan. Sampel diambil dari periode tahun 20152019 dengan metode purposive sampling. Sebanyak 1833 observasi perusahaan dapat dikumpulkan selama periode penelitian. Namun 513 oobservasi harus dieliminasi untuk memenuhi asumsi klasi yang mendasari regresi berganda. Penelitian memasukkan tiga variabel kontrol untuk mengendalikan perbedaan karakteristik sampel perusahaan yaitu ukuran perusahaan, tingkat hutang (leverage), dan profitabilitas. Hasil analisis regresi menunjukkan bahwa: 1) Kepemilikan Institusional tidak berpengaruh signifikan terhadap manajemen laba. 2) Kepemilikan Manajerial tidak berpengaruh signifikan terhadap manajemen laba. 3) Ukuran Komite Audit tidak berpengaruh signifikan terhadap manajemen laba. 4) Ukuran Dewan Komisaris tidak berpengaruh signifikan terhadap manajemen laba. 5) Jenis Kepemilikan berpengaruh signifikan positif terhadap
\end{abstract}


Jurnal Akuntansi Bisnis, Vol. 19, No. 2, September 2021 ISSN 1412-775X (media cetak) | 2541-5204 (media online)

manajemen laba. Sebagai tambahan, dari tiga variabel kontrol yang digunakan ada dua yang berpengaruh terhadap manajemen laba yaitu ukuran perusahaan dan profitabilitas. Sedangkan leverage tidak berpengaruh signifikan terhadap manajemen laba.

\section{Kata Kunci: Manajemen laba, kepemilikan manajerial, Dewan Komisaris, komite audit, struktur kepemilikan.}

\section{PENDAHULUAN}

Sebagai salah satu komponen laporan keuangan, informasi laba membantu investor dalam menilai kinerja perusahaan Gunawan (2017). Investor saham selalu berharap agar perusahaan menghasilkan laba yang tinggi karena laba tinggi memicu kenaikan harga saham. Disamping meningkatkan citra diri di mata investor, laba yang tinggi juga dapat berdampak pada kompensasi yang diterima manajer. Mengingat pentingnya perusahaan membukukan laba yang tinggi tidak jarang manajer mempengaruhi laba yang dilaporkan dengan memilih kebijakan akuntansi tertentu. Praktik seperti ini dikenal sebagai manajemen laba..

Manajemen laba timbul dikarenakan adanya perbedaan kepentingan antara para pemegang saham dengan pihak manajer perusahaan. Eisenhardt (1989) menyatakan bahwa manusia memiliki sifat self-interest, di mana setiap manusia memiliki beberapa sifat dalam memenuhi kepentingannya sendiri, antara lain (1) mengutamakan kepentingan diri sendiri dibandingkan kepentingan orang lain, (2) memiliki kemampuan berpikir terbatas tentang masa yang akan datang, dan (3) memiliki kecenderungan menghindari resiko. Sifat self-interest mendorong manajer melakukan manajemen laba demi memenuhi target pribadi seperti bonus. Kemampuan manajemen dalam meningkatkan laba dapat menentukan bonus yang akan diterima oleh manajer (Naranjo, 2014). Manajer akan melakukan segala upaya untuk mencapai target laba untuk memperoleh bonus.

Pada prinsipnya, manajemen laba bukan pelanggaran akuntansi dan tidak sama dengan fraud. Manajemen laba dilakukan dengan memilih kebijakan akuntansi tertentu yang masih berada dalam koridor prinsip akuntansi yang berterima umum. Yang menjadi kekhawatiran adalah manajemen laba dapat menyesatkan pengguna laporan keuangan karena tidak menampilkan kinerja perusahaan yang sebenarnya (Boediono, 2005). Berbagai penelitian telah dilakukan untuk memahami faktor-faktor yang mempengaruhinya. Boghdady (2019) menunjukkan bahwa struktur kepemilikan memiliki hubungan dengan manajemen laba. Santoso (2015) melaporkan bahwa semakin tinggi kepemilikan institusional maka semakin rendah tingkat manajemen laba. Hasil penelitian tersebut juga didukung oleh hasil penelitian dari Puteri (2012). Hasil-hasil penelitian tersebut mengindikasikan bahwa investor institusional berperan penting dalam meningkatkan pengawasan terhadap manajer sehingga menekan keinginan manajer melakukan manajemen laba.

Faktor selanjutnya yang dapat mempengaruhi manajemen laba adalah kepemilikan manajerial. Hal tersebut dapat terjadi dikarenakan jika pihak manajemen berperan sebagai pemilik saham, kinerja yang mereka lakukan akan mempengaruhi apa yang akan mereka peroleh juga. Sadar bahwa laba yang tidak memenuhi ekspektasi pasar dapat menurunkan harga sehingga kekayaan mereka menurun maka manajer akan berupaya mempengaruhi besaran laba dengan melakukan manajemen laba. Puteri (2012) dan Giarto (2014) memberi bukti bahwa kepemilikan manajerial berpengaruh negatif dan tidak signifikan terhadap manajemen laba.

Faktor lain yang juga dilaporkan mempengaruhi manajemen laba yaitu ukuran Komite Audit. Komite audit memiliki peran untuk menjaga kredibilitas laporan keuangan terutama melalui pengawasan atas penyusunan laporan keuangan (Makhrus, 2019). Santoso (2015) melaporkan 
Jurnal Akuntansi Bisnis, Vol. 19, No. 2, September 2021 ISSN 1412-775X (media cetak) | 2541-5204 (media online)

bahwa komite audit berpengaruh negatif terhadap manajemen laba. Hal tersebut juga didukung oleh Giarto (2014), di mana dalam penelitiannya dapat diketahui bahwa semakin besar anggota komite audit maka potensi terjadinya manajemen laba juga lebih kecil.

Jumlah anggota Dewan Komisaris juga berperan penting dalam meningkatkan fungsi pengawasan (Yermack, 1996). Penelitian Gunawan (2017) menunjukkan bahwa ukuran dewan komisaris berpengaruh negatif terhadap manajemen laba. Semakin banyak jumlah Dewan Komisaris maka fungsi pengawas menjadi lebih efektif dan akhirnya menurunkan motivasi manajer untuk melakukan manajemen laba (Boediono, 2005). Hasil yang konsisten juga dilaporkan Wibowo (2015).

Tujuan dari penelitian ini adalah untuk menguji kembali apakah struktur kepemilikan, ukuran dewan komisaris, dan ukuran komite audit berpengaruh terhadap manajemen laba. Penelitian ini berbeda dengan penelitian sebelumnya karena menambahkan jenis kepemilikan sebagai variabel independen yang diperoleh dari penelitian Boghdady (2019). Hasil penelitian yang dilakukan oleh Boghdady (2019) menunjukkan bahwa jenis kepemilikan mempengaruhi manajemen laba. Penelitian ini juga menambah tiga variabel kontrol yaitu ukuran perusahaan, tingkat hutang (leverage), dan profitabilitas untuk mengontrol perbedaan karakteristik perusahaan yang dapat mempengaruhi hasil penelitian.

\section{LANDASAN TEORI DAN PERUMUSAN HIPOTESIS}

\section{Teori Agensi}

Menurut teori agensi, hubungan antara pihak-pihak yang memiliki kepentingan dengan perusahaan dapat digambarkan sebagai kontrak di mana pemilik (prinsipal) mendelegasikan pengelolaan perusahaan kepada manajer (agen) (Jensen dan Meckling, 1976). Manajer menerima wewenang untuk mengelola perusahaan dan berusaha memenuhi kepentingan pemilik. Namun sifat alami manajer yang lebih mengutamakan kepentingan pribadi dapat merugikan kepentingan pemilik. Eisenhardt (1989) mengemukakan bahwa teori agensi dibangun berdasarkan beberapa asumsi dan salah satunya adalah asumsi bahwa manusia memiliki sifat mementingkan diri sendiri.

Lebih jauh teori agensi menyatakan bahwa pemisahan fungsi kepemilikan dan pengelolaan perusahaan menyebabkan terjadinya asimetri informasi. Dalam bisnis modern, pemilik perusahaan identik dengan para pemegang saham yang menunjuk manajer profesional untuk mengelola perusahaan. Sebagai pengelola perusahaan, manajer memiliki informasi lebih banyak tentang kondisi perusahaan yang sesungguhnya dibandingkan pemegang saham. Kondisi ini dapat memunculkan sifat oportunistik dalam diri manajer dan terdorong memanfaatkan sumber daya perusahaan demi kepentingan pribadi. Eksploitasi sumber daya perusahaan yang semata-mata demi kepentingan pribadi dapat membawa dampak negatif terhadap para pemegang saham. Salah satu contoh tindakan oportunistik yang dilakukan manajer adalah mempengaruhi laba demi tercapainya target laba yang ditetapkan pemegang saham. sehingga merugikan pemilik perusahaan. Tindakan tersebut dikenal secara luas sebagai manajemen laba.

\section{Manajemen Laba}

Investor pasar modal membutuhkan informasi yang cukup untuk menilai kelayakan investasi. Salah satu informasi penting yang bisa digunakan untuk menilai prospek perusahaan adalah informasi laba. Informasi laba menjadi salah satu faktor penting yang membuat investor memutuskan untuk berinvestasi dalam perusahaan (Supriadi dan Gendalasari, 2018). Laba dalam perusahaan mencerminkan kinerja keuangan perusahaan, dan prospek pertumbuhan suatu entitas. 
Jurnal Akuntansi Bisnis, Vol. 19, No. 2, September 2021 ISSN 1412-775X (media cetak) | 2541-5204 (media online)

Untuk mencapai suatu tingkatan laba yang sudah ditargetkan, tidak jarang bagi manajer untuk memutuskan melakukan manajemen laba. Manajemen laba menurut Healy dan Wahlen (1998) adalah intervensi manajer terhadap proses pelaporan keuangan sehingga mempengaruhi laba yang dilaporkan perusahaan. Manajemen laba juga dapat didefinisikan sebagai tindakan manajer untuk meningkatkan (menurunkan) laba yang dilaporkan pada periode berjalan dari sebuah perusahaan tanpa menyebabkan peningkatan (penurunan) ekonomi perusahaan secara jangka panjang (Fischer dan Rosenzweig, 1995). Jadi pada dasarnya manajemen laba merupakan upaya sistematis yang dilakukan manajer untuk menaikkan (menurunkan) laba demi memenuhi target-target pribadi. Tindakan manajemen laba dilakukan dengan memilih kebijakan-kebijakan akuntansi yang dapat menampilkan laporan keuangan menjadi lebih baik.

Manajemen laba yang bertujuan mempercantik laporan keuangan umumnya dilakukan melalui pos-pos akrual yang bersifat diskresioner. Hal ini dimungkinkan karena jumlah pos-pos akrual yang dilaporkan dalam sistem pencatatan perusahaan dipengaruhi diskresi atau pertimbangan manajer. Kebijakan akrual yang dapat mempengaruhi laba diantaranya adalah biaya depresiasi, biaya iklan, dan penentuan biaya hutang tidak tertagih.

Wulandari dkk (2004) dalam Nastiti et al., (2016) menyatakan bahwa tindakan manajemen laba bertujuan untuk mendapatkan bonus dan kompensasi, untuk mempengaruhi pelaku pasar modal atau pengguna laporan keuangan, untuk menghindari biaya politik, dan menghindari pelanggaran perjanjian utang. Lebih detail, Scott (2000) mengemukakan beberapa motivasi yang mendorong manajer melakukan manajemen laba yaitu untuk mendapatkan bonus (bonus purposes), motivasi politik, mitivasi pajak, pergantian CEO, dan motivasi kontraktual.

\section{Tata Kelola Perusahaan}

Menurut Forum for Corporate Governance in Indonesia (2001) dalam Vajriyanti et al. (2019) tata kelola perusahaan adalah seperangkat peraturan yang mengelola hubungan pengurus perusahaan, pemegang saham, karyawan, pemerintah, pihak kreditur, juga pemegang kepentingan internal dan eksternal yang berkaitan dengan hak serta kewajiban mereka yang dapat menimbulkan nilai tambah untuk semua pihak yang berkepentingan. Tata kelola perusahaan yang baik merupakan salah satu faktor penting yang mempengaruhi kepercayaan investor baik terhadap perusahaan maupun lingkungan bisnis.

Prinsip-prinsip dasar penerapan tata kelola perusahaan yang dikemukakan dalam Pedoman Umum Good Corporate Governance (2006) adalah sebagai berikut:

1. Keadilan

Dalam menjalankan kegiatannya, perusahaan diharapkan untuk bersifat setara dan adil untuk pemegang saham dan pemangku kepentingan.

2. Transparansi

Untuk menjaga objektivitas, informasi yang disajikan perusahaan haruslah relevan dan juga mudah untuk diakses serta dipahami oleh pemangku kepentingan.

3. Akuntabilitas

Prinsip ini berkaitan dengan pertanggungjawaban perusahaan terhadap pemegang saham dan pemangku kepentingan lainnya. Perusahaan diharapkan untuk menjalankan kinerjanya secara transparan dan wajar.

4. Pertanggungjawaban

Perusahaan diharapkan untuk menjalankan aktivitas perusahaan sesuai dengan peraturan yang berlaku. Perusahaan juga diharapkan untuk menjalankan tanggung jawab sosial kepada masyarakat atau pemegang kepentingan dengan mementingkan etika bisnis yang baik. 
Jurnal Akuntansi Bisnis, Vol. 19, No. 2, September 2021

ISSN 1412-775X (media cetak) | 2541-5204 (media online)

5. Independensi

Perusahaan harus dikelola secara independen sehingga setiap organ atau bagian dalam perusahaan tidak saling mendominasi dan tidak dapat diintervensi oleh pihak lain.

Untuk mewujudkan lingkungan perusahaan yang baik maka diperlukan mekanisme tata kelola perusahaan yang baik pula. Mekanisme tata kelola perusahaan yang sering digunakan dalam berbagai penelitian mengenai tata kelola perusahaan yaitu komite audit, komisaris independen, kepemilikan institusional, kepemilikan manajerial (Rachmawati dan Triatmoko, 2007).

\section{Kepemilikan Institusional}

Kepemilikan institusional menurut Tarjo (2008) dalam Permanasari (2010) adalah kepemilikan saham perusahaan yang dimiliki oleh institusi seperti perusahaan asuransi, bank, perusahaan investasi dan kepemilikan institusi lain. Kepemilikan oleh investor institusional mendorong peningkatan pengawasan dalam perusahaan menjadi lebih optimal. Investor institusional dipercaya dapat mengatasi konflik keagenan karena dengan meningkatnya kepemilikan institusional maka segala aktivitas perusahaan dapat diawasi juga oleh pihak institusi atau lembaga (Damayanti \& Suartana, 2014).

Kepemilikan institusional menurut Permanasari (2010) memiliki kelebihan antara lain: 1) Memiliki profesionalisme dalam menganalisis informasi sehingga dapat menguji keandalan informasi. 2) Memiliki motivasi yang kuat untuk melaksanakan pengawasan lebih ketat atas aktivitas yang terjadi di dalam perusahaan.

\section{Kepemilikan Manajerial}

Diyah dan Erman (2009) dalam Sukirai (2012) menyatakan bahwa kepemilikan manajemen merupakan proporsi pemegang saham dari pihak manajemen yang secara aktif terlibat dalam pengambilan keputusan perusahaan, pihak manajemen yang dimaksud adalah direktur dan komisaris. Kepemilikan manajerial merupakan kondisi yang menunjukkan bahwa manajer memiliki peran sebagai pemegang saham di perusahaan (Rustiarini, 2010). Hal tersebut ditunjukkan dengan melihat besarnya persentase kepemilikan saham yang dimiliki pihak manajemen perusahaan.

Kepemilikan manajerial dianggap sebagai mekanisme tata kelola yang penting untuk membantu mengendalikan masalah keagenan dan melakukan upaya yang lebih besar untuk menguntungkan perusahaan. Semakin besar persentase saham yang dimiliki oleh manajer, semakin besar kemungkinan manajer akan membuat keputusan yang konsisten dengan memaksimalkan kekayaan pemegang saham (Kamardin, 2014).

Manajer yang memiliki saham perusahaan akan selalu berusaha untuk menyelaraskan kepentingannya sebagai manajer dan juga kepentingannya sebagai pemegang saham. Semakin besar kepemilikan manajerial yang dimiliki manajer di dalam perusahaan maka semakin manajer berusaha pula untuk memaksimalkan nilai perusahaan (Karima et al., 2005).

\section{Dewan Komisaris}

Berdasarkan Undang-Undang Republik Indonesia Nomor 40 Tahun 2007 tentang Perseroan Terbatas, dewan komisaris merupakan organ dalam perseroan yang bertugas untuk melakukan pengawasan secara umum dan khusus sesuai dengan anggaran dasar serta memberikan nasihat kepada direksi. Dewan komisaris sebagai organ perusahaan bertugas dan bertanggung jawab secara untuk melakukan pengawasan dan memberikan nasihat kepada direksi dan 
Jurnal Akuntansi Bisnis, Vol. 19, No. 2, September 2021 ISSN 1412-775X (media cetak) | 2541-5204 (media online)

memastikan bahwa dewan direksi perusahaan akan menjalankan tata kelola perusahaan. Dewan komisaris sebagai wakil pemegang saham yang ditempatkan dalam perusahaan akan memperjuangkan kepentingan para pemegang saham. Dengan adanya dewan komisaris independen, perusahaan mampu menjadi mekanisme tata kelola perusahaan yang tepat untuk mengurangi praktik manajemen laba (Oktaviani, 2015).

Komposisi atau ukuran dewan komisaris harus disusun sesuai dengan kebutuhan sehingga nantinya proses dalam pengambilan keputusan dapat berlangsung secara efektif, tepat, dan cepat. Ukuran dewan komisaris berarti jumlah dewan komisaris yang ada di dalam perusahaan.

Dalam Pedoman Umum Good Corporate Governance (2006), supaya dewan komisaris dapat berjalan secara efektif, maka perlu dipenuhi prinsip-prinsip sebagai berikut: 1) Komposisi Dewan Komisaris harus memungkinkan pengambilan keputusan secara efektif, tepat dan cepat, serta dapat bertindak independen. 2) Anggota Dewan Komisaris harus bersifat profesional, yaitu berintegritas serta memiliki kemampuan sehingga mampu menjalankan fungsi dengan baik. 3) Fungsi pengawasan dan pemberian nasihat Dewan Komisaris mencakup tindakan pencegahan, perbaikan, sampai kepada pemberhentian sementara.

\section{Jenis Kepemilikan}

Di Indonesia tipe kepemilikan perusahaan dibagi menjadi dua yaitu perusahaan Badan Usaha Milik Negara dan Badan Usaha Milik Swasta. Berdasarkan UU No.19 Tahun 2003, Badan Usaha Milik Negara (BUMN) merupakan badan usaha yang keseluruhan atau sebagian besar modalnya dimiliki oleh negara melalui penyertaan secara langsung yang berasal dari kekayaan negara yang dipisahkan (Badan Pusat Statistik). Sedangkan Badan Usaha Milik Swasta (BUMS) adalah badan usaha yang modalnya dimiliki oleh pihak swasta baik itu pihak swasta dalam negeri maupun pihak swasta asing. Alchian (1977) dalam Ding et al., (2007) menyatakan bahwa perusahaan BUMN memerlukan kualitas tata kelola perusahaan yang lebih rendah dibandingkan dengan perusahaan BUMS, hal ini dikarenakan adanya masalah kemampuan dalam menjalankan kontrak yang telah disepakati.

\section{Kepemilikan Institusional dan Manajemen Laba}

Kepemilikan institusional merupakan persentase kepemilikan saham yang dimiliki oleh institusi. Investor institusional memiliki peranan penting dalam tata kelola perusahaan dikarenakan aktivitas pengawasan (monitoring) yang dilakukan. Berdasarkan teori agensi fungsi pengawasan yang dimiliki investor institusional dapat menjadi salah satu mekanisme tata kelola perusahaan yang dapat mengurangi kemungkinan terjadinya konflik antara manajer dan investor. Dengan adanya kepemilikan saham oleh investor institusional maka pengawasan terhadap jalannya perusahaan semakin ketat. Investor institusional memiliki kemampuan lebih dalam melakukan pengawasan dibanding investor individu karena memiliki sumber daya dan kemampuan yang cukup dalam melakukan pengawasan. Investor institusional tidak mudah diperdaya dengan tindakan manipulasi yang dilakukan oleh pihak manajemen (Rachmawati \& Triatmoko, 2007). Dengan adanya peran pengawasan yang dilakukan oleh investor institusional maka peluang bagi manajer untuk melakukan manajemen laba akan berkurang.

Argumen diatas didukung hasil dari penelitian Midiastuty dan Machfoedz (2003) dan Boediono (2005) yang memperlihatkan bahwa kepemilikan institusional berpengaruh positif terhadap kualitas laba yang dilaporkan. Hasil penelitian tersebut juga didukung oleh hasil penelitian dari Puteri (2012) dan Santoso (2015) yang melaporkan bahwa semakin tinggi kepemilikan institusional maka semakin rendah tingkat manajemen laba. Jadi, kepemilikan 
institusional dapat menjadi salah satu mekanisme tata kelola perusahaan yang mencegah perilaku oportunistik manajer untuk memanfaatkan diskresi akuntansi yang dimiliki demi memperoleh keuntungan pribadi. Berdasarkan uraian tersebut, maka hubungan kepemilikan institusional dan manajemen laba dapat dinyatakan dalam hipotesis berikut:

H1: Kepemilikan institusional berpengaruh negatif terhadap Manajemen Laba

\section{Kepemilikan Manajerial dan Manajemen Laba}

Kepemilikan manajerial merupakan jumlah dari persentase kepemilikan saham yang dimiliki oleh manajemen perusahaan. Menurut Midiastuty dan Machfoedz (2003), kepemilikan manajerial merupakan salah satu cara untuk membatasi perilaku oportunistik manajer dalam melakukan manajemen laba. Konflik kepentingan antara manajer dan investor akan berkurang apabila manajer sebuah perusahaan juga memiliki saham perusahaan. Dengan adanya kepemilikan manajerial dalam perusahaan, maka hal tersebut akan membuat manajer termotivasi untuk bekerja lebih baik demi kepentingan para pemegang saham.

Manajer yang memiliki saham perusahaan juga dapat dikatakan sebagai investor. Kepemilikan saham perusahaan dapat mendorong manajer untuk mengurangi kepentingan pribadi dan bertindak dengan lebih memikirkan perusahaan agar dapat berkembang secara lebih optimal. Penelitian Warfield et al., (1995) dan Midiastuty dan Machfoedz (2003) memberi bukti bahwa kepemilikan manajerial memiliki pengaruh negatif terhadap manajemen laba. Hasil penelitian tersebut juga didukung oleh penelitian yang dilakukan Puteri (2012), Giarto (2014), dan Santoso (2015). Berdasarkan uraian tersebut, maka hubungan kepemilikan manajerial dan manajemen laba dapat dinyatakan dalam hipotesis berikut:

\section{H2: Kepemilikan Manajerial berpengaruh negatif terhadap Manajemen Laba}

\section{Ukuran Komite Audit dan Manajemen Laba}

Komite Audit dibentuk untuk membantu dewan komisaris dalam melakukan fungsi pengawasan terutama pada proses pelaporan keuangan perusahaan. fungsi pengawasan yang dilakukan Komite Audit memperkecil ruang yang ada bagi manajer untuk mempengaruhi atau mengintervensi proses pelaporan keuangan. Santoso (2015) melaporkan bahwa ukuran Komite Audit berpengaruh negatif terhadap manajemen laba. Komite Audit mengurangi risiko ketidaktepatan dalam pemilihan kebijakan akuntansi sehingga dapat mencegah terjadinya tindakan manajemen laba. Hal tersebut juga didukung oleh Giarto (2014), di mana dalam penelitiannya dapat diketahui bahwa semakin besar anggota Komite Audit maka potensi terjadinya manajemen laba juga lebih kecil.

Hasil penelitian Nasution dan Setiawan (2007) menunjukkan bahwa ukuran komite audit memiliki pengaruh terhadap manajemen laba. Hasil tersebut menunjukkan bahwa semakin banyak anggota Komite Audit maka semakin efektif fungsi pengawasan yang dijalankan Komite Audit. Keberadaan Komite Audit dapat mengurangi kemungkinan terjadinya praktik kecurangan dalam pelaporan keuangan, serta dapat membantu mengurangi terjadinya praktik manajemen laba. Semakin besarnya jumlah komite maka dapat diartikan semakin banyak pula personil yang terlibat dalam melakukan pengawasan, sehingga peluang bagi manajer untuk melakukan manajemen laba dapat berkurang. Berdasarkan uraian tersebut, maka hubungan ukuran komite audit dan manajemen laba dapat dinyatakan dalam hipotesis berikut:

\section{H3: Ukuran Komite Audit berpengaruh negatif terhadap Manajemen Laba}




\section{Ukuran Dewan Komisaris dan Manajemen Laba}

Menurut Undang-Undang Republik Indonesia Nomor 40 Tahun 2007 tentang Perseroan Terbatas, Dewan Komisaris merupakan organ dalam perseroan yang bertugas untuk melakukan pengawasan secara umum dan khusus sesuai dengan anggaran dasar serta memberikan nasihat kepada direksi. Dewan Komisaris sebagai wakil dari para investor yang ditempatkan dalam perusahaan akan memperjuangkan kepentingan para investor. Keberadaan Dewan Komisaris akan meyakinkan investor bahwa manajemen telah diawasi dan akan bertindak sesuai dengan kepentingan para investor.

Penelitian yang dilakukan oleh Chtourou et al., (2001) menemukan bahwa ukuran dewan komisaris berpengaruh negatif terhadap manajemen laba, di mana hal ini menunjukkan bahwa semakin besar proporsi Dewan Komisaris maka semakin kecil peluang terjadinya manajemen laba. Dalam penelitian Sumanto \& Asrori (2014) dapat diketahui bahwa semakin sedikit anggota Dewan Komisaris maka memungkinkan bagi organisasi tersebut untuk didominasi oleh pihak manajemen yang nantinya akan memanfaatkan peluang mereka untuk melakukan manajemen laba. Semakin banyak Dewan Komisaris maka akan semakin luas pula cakupan pengawasannya. Selain itu semakin banyak Dewan Komisaris maka dapat pula diartikan bahwa semakin banyak pula wakil dari para investor sehingga hal tersebut dapat menekan potensi terjadinya manajemen laba. Oleh karena itu ukuran Dewan Komisaris dalam perusahaan dapat berpengaruh terhadap risiko terjadinya manajemen laba.

Hal tersebut juga didukung oleh penelitian Gunawan (2017) dan Santoso (2015) yang menunjukkan bahwa ukuran dewan komisaris berpengaruh negatif terhadap manajemen laba. Berdasarkan uraian tersebut, maka hubungan ukuran dewan komisaris dan manajemen laba dapat dinyatakan dalam hipotesis berikut:

\section{H4: Ukuran Dewan Komisaris berpengaruh negatif terhadap Manajemen Laba}

\section{Jenis Kepemilikan dan Manajemen Laba}

Hasil penelitian Chen dan Zhang (2014) menunjukkan bahwa peran komite audit dan dewan komisaris cenderung lebih efektif pada perusahaan dengan kepemilikan swasta daripada perusahaan yang sahamnya dimiliki negara. Chen dan Zhang (2014) menyatakan bahwa lebih sulit untuk mengendalikan masalah keagenan pada perusahaan milik negara dikarenakan pemilik perusahaan adalah negara itu sendiri sehingga cakupan kerja lebih luas dan berisiko. Semakin luas cakupan perusahaan maka akan semakin susah pula untuk dilakukan kendali dan kontrol.

Perbedaan lingkungan dan tata kelola perusahaan yang diterapkan pada perusahaan yang mayoritas kepemilikan saham dimiliki swasta dan yang dimiliki pemerintah dapat mempengaruhi peluang terjadinya manajemen laba. Chen dan Zhang (2014) menyatakan bahwa perusahaan dengan tipe Badan Usaha Milik Swasta akan memiliki masalah keagenan yang lebih kecil dibandingkan perusahaan yang sebagian besar sahamnya dimiliki negara. Para manajer yang bekerja dalam perusahaan yang sahamnya dimiliki swasta memiliki rasa tanggung jawab yang lebih besar terhadap para pemegang saham sehingga mendahulukan kepentingan para pemegang saham daripada kepentingan pribadi. Dalam memanfaatkan sumber daya yang dimiliki perusahaan, mereka cenderung lebih efisien serta menghindari praktik bisnis dan praktik pelaporan keuangan yang dapat merugikan pemegang saham. Di sisi lain, manajer perusahaan yang mayoritas sahamnya dimiliki negara cenderung lebih mementingkan diri sendiri dan cenderung bertindak oportunistik. Dengan demikian patut diduga bahwa praktik manajemen laba akan lebih besar pada perusahaan yang dikuasai negara dibandingkan perusahaan yang dikuasai pihak swasta. 
Jurnal Akuntansi Bisnis, Vol. 19, No. 2, September 2021 ISSN 1412-775X (media cetak) | 2541-5204 (media online)

Berdasarkan uraian tersebut, maka hubungan jenis kepemilikan dan manajemen laba dapat dinyatakan dalam hipotesis berikut:

H5: Manajemen laba perusahaan yang dikuasai negara lebih tinggi daripada perusahaan yang dikuasai pihak swasta.

\section{METODE PENELITIAN}

\section{Populasi dan Sampel}

Populasi dalam penelitian ini merupakan seluruh perusahaan yang telah terdaftar dalam Bursa Efek Indonesia (BEI), kecuali perusahaan yang berada di sektor bank dan finansial. Metode sampel yang dipakai ialah purposive sampling dengan kriteria sebagai berikut :

1. Seluruh perusahaan yang terdaftar di Bursa Efek Indonesia (kecuali perusahaan di sektor perbankan dan finansial) tahun 2015-2019

2. Perusahaan yang laporan keuangannya dalam Rupiah

3. Perusahaan memiliki data yang cukup lengkap terkait informasi Kepemilikan Manajerial, Kepemilikan Institusional, Ukuran Dewan Komisaris, Ukuran Komite Audit, Jenis Kepemilikan.

Berdasarkan kriteria pengambilan sampel di atas, sebanyak 1833 observasi perusahaan memenuhi kriteria dan layak untuk dianalisis lebih lanjut. Tabel 1 menyajikan secara detail proses seleksi pemilihan sampel.

Tabel 1. Seleksi Pemilihan Sampel

\begin{tabular}{|l|r|r|r|r|r|r|}
\hline Kriteria & 2015 & 2016 & 2017 & 2018 & 2019 & Total \\
\hline $\begin{array}{l}\text { Perusahaan Terdaftar di BEI ( kecuali } \\
\text { sektor perbankan dan financial) }\end{array}$ & 399 & 465 & 505 & 558 & 600 & 2527 \\
\hline $\begin{array}{l}\text { Perusahaan menyajikan laporan } \\
\text { keuangan dalam Rupiah }\end{array}$ & $(51)$ & $(87)$ & $(90)$ & $(93)$ & $(97)$ & $(418)$ \\
\hline $\begin{array}{l}\text { Perusahaan tidak memiliki data } \\
\text { lengkap terkait variabel manajemen } \\
\text { laba }\end{array}$ & $(9)$ & $(11)$ & $(13)$ & $(9)$ & $(13)$ & $(55)$ \\
\hline $\begin{array}{l}\text { Perusahaan tidak memiliki data } \\
\text { lengkap terkait struktur kepemilikan }\end{array}$ & $(24)$ & $(40)$ & $(43)$ & $(51)$ & $(63)$ & $(221)$ \\
\hline Jumlah Sampel & 315 & 327 & 359 & 405 & 427 & 1833 \\
\hline
\end{tabular}

\section{Definisi dan Pengukuran Variabel}

\section{Manajemen Laba}

Manajemen laba merupakan variabel dependen yang digunakan di dalam penelitian ini. Manajemen laba adalah tindakan yang dilakukan oleh manajer perusahaan dengan tujuan untuk mempengaruhi informasi yang nantinya akan diungkapkan dalam laporan keuangan. Discretionary Accruals menjadi proksi dari manajemen laba dan dapat ditemukan dengan menggunakan Modified Jones Model. Discretionary accruals merupakan bagian akrual dari hasil 
Jurnal Akuntansi Bisnis, Vol. 19, No. 2, September 2021 ISSN 1412-775X (media cetak) | 2541-5204 (media online)

rekayasa manajer dengan cara menggunakan kebebasan dalam membuat perkiraan dan penggunaan standar akuntansi. Untuk mengetahui besar discretionary accruals, terlebih dulu menghitung total akrual untuk tiap perusahaan i di tahun t dengan metode modifikasi Jones, yaitu:

1. Menghitung Total Accruals

$$
\text { TACit }=\text { NIit }- \text { CFOit }
$$

Keterangan:

TACit $=$ Total Accruals perusahaan i pada periode ke $\mathrm{t}$ (sekarang);

Nlit $\quad=$ Laba Bersih perusahaan i pada periode ke $\mathrm{t}$ (sekarang);

CFOit $\quad=$ Aliran Kas aktivitas operasi perusahaan i pada periode ke $\mathrm{t}$ (sekarang).

2. Mengestimasi Total Accrual (TAC) dengan Ordinary Least Square (OLS) untuk mendapatkan koefisien regresi

$$
\frac{T A C_{t}}{T A_{t-1}}=\beta_{1} \frac{1}{T A_{t-1}}+\beta_{2} \frac{\Delta R E V_{t}}{T A_{t-1}}+\beta_{3} \frac{P P E_{t}}{T A_{t-1}}+e
$$

Keterangan: $\quad \Delta \mathrm{REV}=$ Perubahan pendapatan perusahaan antara periode $\mathrm{t}-1$ dan $\mathrm{t}$; $\mathrm{PPE}_{\mathrm{t}}=$ Aset tetap perusahaan pada periode

3. Menghitung nondiscretionary accruals (NDA)

$$
N D A_{t}=\propto_{1} \frac{1}{T A_{t-1}}+\propto_{2} \frac{\Delta R E V_{t} \quad \Delta R E C_{t}}{T A_{t-1}}+\propto_{3} \frac{P P E_{t}}{T A_{t-1}}
$$

Keterangan: $\Delta \mathrm{REC}_{\mathrm{t}}=$ Perubahan pada piutang perusahaan antara periode $\mathrm{t}-1 \mathrm{dan} \mathrm{t}$

4. Menghitung discretionary accruals (DA) sebagai ukuran dari manajemen laba

$$
\text { DAit }=(\text { TACit } / \text { TAit }-1)-\text { NDAit }
$$

Keterangan:

DACt $=$ discretionary accruals perusahaan pada periode $\mathrm{t}$

TACt $=$ discretionary accruals total perusahaan dalam periode $\mathrm{t}$

TAt-1 = aset total perusahaan pada akhir periode $\mathrm{t}-1$

$\mathrm{NDA}_{\mathrm{t}} \quad=$ non-discretionary accruals perusahaan pada periode $\mathrm{t}$.

\section{Kepemilikan Manajerial}

Diyah dan Erman (2009) dalam Sukirai (2012) menyatakan bahwa kepemilikan manajemen merupakan proporsi pemegang saham dari pihak manajemen yang secara aktif terlibat dalam pengambilan keputusan perusahaan. Semakin tinggi proporsi kepemilikan manajemen di dalam perusahaan maka hal tersebut akan mampu menyatukan kepentingan manajer dan pemegang saham yang mengakibatkan kinerja perusahaan semakin baik. Kepemilikan manajerial diukur dengan menggunakan persentase jumlah saham yang dimiliki manajemen dari total saham beredar (Ujiyantho dan Agus Pramuka, 2007).

\section{Kepemilikan Institusional}

Kepemilikan institusional merupakan kepemilikan saham perusahaan yang dimiliki oleh institusi seperti bank, perusahaan asuransi, dan institusi lainnya. Kepemilikan institusional 
Jurnal Akuntansi Bisnis, Vol. 19, No. 2, September 2021 ISSN 1412-775X (media cetak) | 2541-5204 (media online)

merupakan saham yang dimiliki oleh suatu institusi baik dari dalam atau luar negeri. Kepemilikan institusional diukur dengan menggunakan skala rasio dengan melihat jumlah saham yang dimiliki oleh investor institusional yang dibandingkan dengan keseluruhan total saham perusahaan (Guna dan Herawaty, 2010).

\section{Ukuran Dewan Komisaris}

Semakin banyak dan semakin besar ukuran dewan komisaris, maka semakin tinggi juga tingkat pengawasan yang dilakukan. Ukuran dewan komisaris yang besar akan menekan risiko terjadinya manajemen laba dalam perusahaan (Nasution \& Setiawan, 2007). Ukuran Dewan Komisaris diproksikan melalui jumlah dewan komisaris yang dimiliki perusahaan.

\section{Ukuran Komite Audit}

Komite Audit memiliki pengaruh pada laporan keuangan antara lain berkurangnya risiko atas ketidaktepatan dalam pengukuran dan pengungkapan akuntansi. Semakin besar ukuran komite audit dalam perusahaan maka peluang terjadinya manajemen laba juga akan menurun. Ukuran Komite Audit diproksikan melalui jumlah dewan komisaris yang dimiliki perusahaan.

\section{Jenis Kepemilikan}

Dalam penelitian yang dilakukan oleh Boghdady (2019) dapat diketahui bahwa jenis kepemilikan suatu perusahaan juga menentukan peluang terjadinya manajemen laba. Perusahaan yang dikendalikan oleh negara dan swasta akan diberi kode untuk pengelompokkan. Untuk menguji pengaruh yang ada maka akan dibentuk variabel dummy di mana kode 1 jika perusahaan dikendalikan oleh negara dan 0 jika dikendalikan oleh swasta.

\section{Leverage}

Leverage merupakan perbandingan antara total kewajiban dengan total aktiva perusahaan. Rasio ini menggambarkan besar aktiva yang dimiliki perusahaan yang dibiayai dengan hutang. Makin banyak hutang, maka semakin besar juga risiko bagi suatu perusahaan untuk tidak mampu membayar hutangnya. Rasio pengukuran leverage pada penelitian ini menggunakan pengukuran Debt to Equity Ratio (DER).

\section{Ukuran Perusahaan}

Ukuran perusahaan merupakan ukuran dari sebuah perusahaan yang penilaiannya ditentukan dengan menghitung jumlah aset yang dimiliki perusahaan. Perusahaan yang berukuran lebih besar cenderung kurang memiliki motivasi untuk melakukan manajemen laba dibanding perusahaan kecil, hal tersebut dikarenakan perusahaan kecil cenderung memiliki lebih banyak risiko. Jumlah aset yang dimiliki perusahaan kemudian ditransformasi dalam bentuk logaritma natural $(\mathrm{LN})$.

\section{Profitabilitas}

Profitabilitas menggambarkan kemampuan untuk memperoleh laba dari aktivitas bisnis yang dilakukan perusahaan. Dalam penelitian ini rasio profitabilitas yang digunakan adalah ROA (Return on Assets) yaitu laba bersih perusahaan setelah pajak dibagi dengan total asset. 


\section{Model Regresi}

Penelitian ini meneliti tentang pengaruh kepemilikan manajerial, kepemilikan institusional, ukuran Dewan Komisaris, ukuran Komite Audit, jenis kepemilikan terhadap manajemen laba. Pengujian hipotesis menggunakan analisis linear berganda dengan model regresi:

$$
\begin{aligned}
\mathrm{Man} \_\mathrm{Lab}= & \beta 0+\beta 1 \mathrm{KMANJ}+\beta 2 \mathrm{KINST}+\beta 3 \mathrm{UDKOM}+\beta 4 \mathrm{UKAUD} \\
& +\beta 5 \mathrm{JKEP}+\beta 6 \mathrm{LEV}+\beta 7 \mathrm{SIZE}+\beta 5 \mathrm{PROF}+e
\end{aligned}
$$

Keterangan:

Man_Lab = Discretionary Accruals periode $\mathrm{t}$

KMANJ = Kepemilikan Manajerial

KINST $\quad=$ Kepemilikan Institusional

UDKOM = Ukuran Dewan Komisaris

UKAUD = Ukuran Komite Audit

JKEP $\quad=$ Jenis Kepemilikan

LEV $\quad=$ Leverage

SIZE $\quad=$ Ukuran Perusahaan

PROF $\quad=$ Profitabilitas

Discretionary Accruals (DA) yang diperoleh dari model regresi diatas ditransformasi kedalam nilai absolut yang bertujuan untuk menghindari nilai DA negatif yang bersifat menurunkan laba dan DA positif yang bersifat menaikkan laba untuk saling meniadakan (cancel out).

\section{HASIL DAN PEMBAHASAN}

\section{Statistik Deskriptif}

Penelitian dilakukan dari periode 2015 - 2019 pada perusahaan go public (kecuali sektor keuangan) yang terdaftar di Bursa Efek Indonesia. Sektor keuangan dikeluarkan dari sampel karena memiliki karakteristik akrual yang berbeda. Seperti yang telah dikemukakan sebelumnya, sebanyak 1833 observasi tersedia untuk pengujian hipotesis. Namun sebanyak 513 observasi harus dieliminasi untuk memenuhi asumsi klasik, sehingga data yang dapat digunakan adalah 1320 observasi. Tabel 2 menyajikan statistik deskriptif dari seluruh variabel yang digunakan dalam penelitian.

Tabel 2. Statistik Deskriptif

\begin{tabular}{|l|c|r|r|r|r|}
\hline Variabel & $\mathrm{N}$ & \multicolumn{1}{|c|}{ Minimum } & \multicolumn{1}{c|}{ Maksimum } & \multicolumn{1}{c|}{ Rata-rata } & $\begin{array}{l}\text { Standar } \\
\text { Deviasi }\end{array}$ \\
\hline KINST & 1320 & 0,000 & 0,980 & 0,307 & 0,329 \\
\hline KMANJ & 1320 & 0,000 & 0,778 & 0,029 & 0,091 \\
\hline UKAUD & 1320 & 2,000 & 6,000 & 3,052 & 0,375 \\
\hline UDK & 1320 & 2,000 & 9,000 & 3,920 & 1,577 \\
\hline JKEP & 1320 & 0,000 & 1,000 & 0,039 & 0,193 \\
\hline dummy $)$ & 1320 & 24,581 & 44,715 & 28,388 & 1,642 \\
\hline SIZE & 1320 & $-10,889$ & 2,986 & 0,014 & 0,438 \\
\hline ROA & 1320 & $-25,959$ & 41,215 & 1,273 & 2,995 \\
\hline DER & 1320 & & &
\end{tabular}

Sumber: Data Sekunder yang Diolah (2021) 
Jurnal Akuntansi Bisnis, Vol. 19, No. 2, September 2021 ISSN 1412-775X (media cetak) | 2541-5204 (media online)

Dari Tabel 2 dapat dilihat bahwa kepemilikan institusional (KINST) memiliki nilai minimum sebesar 0,000 yang di mana dapat diartikan bahwa tidak terdapat investor institusional di perusahaan. Nilai maksimum sebesar 0,980 menunjukkan kepemilikan PT. Gunawan Dianjaya Steel pada tahun 2015. Sedangkan nilai rata-rata 0,307 serta standar deviasinya sebesar 0,329. Hal tersebut menunjukkan bahwa terdapat perbedaan antar data cukup tinggi karena nilai standar deviasi lebih besar dibandingkan nilai rata-ratanya. Rata-rata 0,307 menunjukkan bahwa secara rata-rata investor institusional memiliki kepemilikan saham sebesar $31 \%$.

Selanjutnya untuk variabel kepemilikan manajerial (UKMANJ) memiliki nilai minimum sebesar 0,000 dan nilai maksimum sebesar 0,778 dengan nilai rata-rata sebesar 0,029 dan standar deviasi sebesar 0,091. Nilai minimum 0,000 diartikan bahwa pihak manajemen perusahaan tidak memiliki saham di perusahaan terkait dan nilai maksimum dimiliki oleh PT. Saranacentral Bajatama pada tahun 2015. Nilai rata-rata sebesar 0,029 menunjukkan bahwa saham perusahaan yang dimiliki oleh pihak manajemen rata-rata adalah sebesar 2,9\%.

Ukuran komite audit (UKAUD) memiliki nilai minimum sebesar 2 dan nilai maksimum sebesar 6, sedangkan nilai rata-rata sebesar 3,052. Nilai minimum dimiliki oleh PT. Martina Berto tbk pada tahun 2019, hal ini sendiri menyalahi aturan dari Otoritas Jasa Keuangan. Nilai maksimum sendiri menggambarkan komite audit pada PT. Wijaya Karya Tbk pada tahun 2019. Nilai rata-rata sebesar 3,052 menggambarkan bahwa rata-rata jumlah personil komite audit di suatu perusahaan adalah 3 personil. Hal ini sudah sesuai dengan peraturan dari Otoritas Jaksa Keuangan tentang Tata Kelola Perusahaan bahwa perusahaan seharusnya memiliki minimal 3 personil komite audit.

Ukuran dewan komisaris (UDK) memiliki nilai minimum sebesar 2 dan nilai maksimum sebesar 9, sedangkan nilai rata-rata sebesar 3,920. Nilai minimum 2 merupakan ukuran dewan komisaris dari PT. Saraswati Griya Lestari dan nilai maksimum 9 menggambarkan ukuran dewan komisaris PT. XL Axiatama Tbk tahun 2019. Standar deviasi sebesar 1,577. Nilai rata-rata sebesar 3,920 menunjukkan bahwa rata-rata jumlah anggota dewan komisaris di suatu perusahaan adalah 3 hingga 4 personil.

Variabel jenis kepemilikan (JKEP) merupakan variabel dummy yang diberi nilai 1 jika sebagian saham perusahaan dimiliki pemerintah dan 0 jika tidak ada saham perusahaan yang dimiliki pemerintah. Contoh perusahaan dengan saham yang dimiliki oleh pemerintah adalah PT. Jasa Marga Tbk, sedangkan contoh untuk perusahaan non pemerintah adalah PT. Astra Agro Lestari.

Variabel ukuran perusahaan (SIZE) memiliki nilai minimum sebesar 24,581 dan nilai maksimum 44,715, rata-rata yang dimiliki sebesar 28,388. Nilai minimum menggambarkan ukuran perusahaan PT. Protech Mitra Perkasa tbk tahun 2019 dan nilai maksimum menggambarkan PT. Ciputra Development Tbk tahun 2015. Hasil dari standar deviasi atau penyimpangannya adalah sebesar 1,642.

Variabel profitabilitas (ROA) memiliki nilai minimum sebesar $-10,889$ untuk PT. Trikomsel Oke Tbk tahun 2015 dan nilai maksimum 2,986 untuk PT. Hotel Mandarine Regency Tbk tahun 2015. Selain itu, nilai rata-rata ROA adalah sebesar 0,014 dan standar deviasi sebesar 0,438. Hal tersebut menggambarkan bahwa profitabilitas perusahaan sampel memiliki rata-rata sebesar $1,4 \%$.

Variabel tingkat hutang (DER) memiliki nilai minimum sebesar -25,959 dan nilai maksimum 41,215. Nilai maksimum dari DER menunjukkan bahwa perusahaan memiliki hutang 41,215 kali dibandingkan dengan jumlah modal yang dimiliki. Selain itu, nilai rata-rata DER adalah 1,273 dengan deviasi standar sebesar 2,995. Rata-rata DER yang berada di atas 1 
Jurnal Akuntansi Bisnis, Vol. 19, No. 2, September 2021 ISSN 1412-775X (media cetak) | 2541-5204 (media online)

menandakan bahwa nilai rata-rata tersebut cukup tinggi. Nilai minimum menggambarkan DER dari PT. Bakrie Sumatera Plantations Tbk pada 2017 dan nilai maksimum menggambarkan PT. Central Proteina Prima tahun 2016. Rasio leverage yang tinggi mencerminkan dua hal, yakni yang pertama yaitu tentang bagaimana perusahaan memiliki optimisme dalam berprospek dan cerminan yang kedua adalah tingginya leverage perusahaan menandakan risiko yang dihadapi perusahaan cukup tinggi.

\section{Pengaruh Likuiditas Terhadap Kualitas Laba}

Hasil uji regresi atas pengaruh likuiditas terhadap kualitas laba menunjukkan nilai signifikansi sebesar 0,459 atau lebih besar dari 0,05 dengan nilai koefisien regresi sebesar 0,067. Berdasarkan penjelasan mengenai hasil tersebut dapat disimpulkan bahwa likuiditas tidak berpengaruh terhadap kualitas laba. Tingkat likuiditas sebuah perusahaan tidak memengaruhi kualitas laba yang dihasilkan. Hal ini dikarenakan likuiditas tinggi yang dimiliki oleh perusahaan tidak menjamin bahwa manajemen perusahaan dapat mengelola perusahaan dengan baik, sehingga kualitas laba yang dihasilkan baik. Semakin tinggi likuiditas sebuah perusahaan, akan semakin mudah perusahaan tersebut memperoleh pendanaan dari pihak ketiga. Sehingga manajemen akan terus berupaya untuk mempertahankan tingkat likuiditas perusahaan yang tinggi daripada kinerja perusahaan yang baik, hal ini akan mengganggu operasional perusahaan. Apabila likuiditas perusahaan terlalu besar maka perusahaan akan sulit mengelola aset lancarnya semaksimal mungkin, hal ini akan berdampak pada kinerja perusahaan yang kurang baik sehingga besar kemungkinan perusahaan tersebut melakukan manajemen laba. Hasil pada penelitian ini mematahkan teori sinyal atas likuiditas perusahaan.

Hasil penelitian ini memperkuat penelitian yang dilakukan oleh Kurniawan (2017), Priyandani (2020) dan Salma (2019) yang menyatakan bahwa likuiditas tidak berpengaruh terhadap kualitas laba. Tingkat likuiditas sebuah perusahaan tidak menjamin bahwa perusahaan tersebut menghasilkan laba yang berkualitas.

\section{Pengaruh Kepemilikan Manajerial Terhadap Manajemen Laba}

Kepemilikan manajerial merupakan kondisi dimana manajer perusahaan memiliki saham dan berperan sebagai pemegang saham di dalam perusahaan. Dalam penelitian ini, yang dianalisis melalui uji hipotesis dapat diketahui bahwa kepemilikan manajerial tidak berpengaruh dalam tindakan manajemen laba. Hasil dari pengujian ini juga sesuai dengan penelitian yang dilakukan oleh Lamora et al., (2012) dan Fadilla (2013).

Jumlah saham yang dimiliki oleh manajemen perusahaan tidak mempengaruhi ada tidaknya tindakan manajemen laba yang dilakukan oleh perusahaan. Midiastuty (2005) dan Gideon (2005) menjelaskan dalam penelitiannya bahwa mekanisme kepemilikan manajerial dalam tata kelola perusahaan terbilang cukup lemah dan kurang efektif. Hal tersebut dapat terjadi dikarenakan jumlah kepemilikan manajerial untuk perusahaan yang terdaftar di Bursa Efek Indonesia relatif lebih sedikit, saham yang berada di perusahaan cenderung dimiliki oleh investor dari luar perusahaan. Dengan saham yang terbatas yang dimiliki oleh manajer, maka dapat disimpulkan bahwa kepentingan antara manajer dan pemegang saham tidak memiliki pengaruh terhadap terjadi atau tidaknya tindakan manajemen laba di dalam perusahaan.

\section{Pengaruh Ukuran Komite Audit Terhadap Manajemen Laba}

Pemegang saham di suatu perusahaan akan memberikan kepercayaannya pada direktur utama perusahaan untuk mengelola dan mengawasi keuangan di perusahaan tempat mereka 
Jurnal Akuntansi Bisnis, Vol. 19, No. 2, September 2021 ISSN 1412-775X (media cetak) | 2541-5204 (media online)

berinvestasi. Direktur perusahaan memberikan dan menyerahkan tanggung jawab tersebut kepada komite audit.

Hasil pengujian mendapatkan bahwa Ukuran Komite Audit yang diproksikan dengan jumlah komite audit, tidak berpengaruh signifikan terhadap manajemen laba, sehingga H3 ditolak. Hasil penelitian ini sejalan dengan penelitian Noviardhi dan Hadiprajitno (2013) di mana dalam penelitian tersebut disebutkan bahwa keberadaan komite audit semata-mata dianggap sebagai pemenuhan regulasi perusahaan dan juga tidak menutup kemungkinan bahwa komite audit masih dapat dipengaruhi kinerjanya oleh dewan komisaris.

Untuk menekan risiko terjadinya manajemen laba, keefektivitasan komite audit tidak dapat dilihat melalui ukuran komite audit dalam perusahaan melainkan dengan mempertimbangkan beberapa faktor lain seperti kualitas dan kemampuan komite audit.

\section{Pengaruh Ukuran Dewan Komisaris Terhadap Manajemen Laba}

Dewan Komisaris merupakan organ perusahaan yang bertanggung jawab dalam melakukan pengawasan dan memberikan nasihat kepada direksi (Pedoman Umum Good Corporate Governance Indonesia, 2006). Hasil pengujian mendapatkan bahwa Ukuran Dewan Komisaris yang diproksikan dengan jumlah dewan komisaris, tidak berpengaruh terhadap manajemen laba.

Hasil dari penelitian ini juga sejalan dengan penelitian yang dilakukan oleh Launa dan Respati (2017). Dengan kata lain, seberapa banyak jumlah dewan komisaris yang berada di dalam perusahaan tidak memiliki pengaruh atas terjadi atau tidaknya tindakan manajemen laba di perusahaan.

Dewan komisaris yang tidak maksimal dalam melakukan pengawasan memungkinkan manipulasi dalam proses penyajian laporan keuangan oleh manajemen, oleh karena itu tindakan manajemen laba tidak dapat dikendalikan oleh anggota Komisaris Independen berapapun jumlahnya.

\section{Pengaruh Jenis Kepemilikan Terhadap Manajemen Laba}

Hasil penelitian ini sejalan dengan penelitian yang dilakukan oleh Chen dan Zhang (2014), di mana kinerja atau peran dewan komisaris dapat berjalan efektif tergantung dengan jenis kepemilikan perusahaan. Jenis kepemilikan terbagi menjadi perusahaan yang sahamnya dimiliki oleh pemerintah dan yang sahamnya tidak dimiliki oleh pemerintah.

Dalam penelitian Chen dan Zhang (2014) disebutkan bahwa komponen tata kelola perusahaan cenderung lebih efektif penerapannya pada perusahaan dengan kepemilikan non pemerintah atau swasta daripada perusahaan yang sahamnya dimiliki pemerintah. Hal tersebut dapat terjadi dengan didasari oleh beberapa faktor seperti perbedaan lingkungan ataupun sistem yang mungkin berbeda di masing-masing perusahaan. Oleh karena itu, jenis kepemilikan berpengaruh terhadap peluang terjadinya manajemen laba. Di mana hasil dari penelitian ini menunjukkan bahwa manajemen laba perusahaan yang dikuasai negara cenderung lebih tinggi daripada perusahaan yang dikuasai pihak swasta.

\section{Pengaruh Ukuran Perusahaan terhadap Manajemen Laba}

Hasil penelitian menyatakan bahwa ukuran perusahaan berpengaruh signifikan terhadap manajemen laba pada perusahaan yang terdaftar di Bursa Efek Indonesia periode 2015-2029. Ukuran perusahaan memiliki pengaruh terhadap terjadinya praktik manajemen laba.

Beberapa perusahaan memiliki pemikiran apabila total aset yang dimiliki perusahaan banyak maka risiko manajemen laba akan turun sedangkan terdapat juga pandangan dimana 
melalui peningkatan aset dapat maka peluang terjadinya manajemen laba akan terbuka. Dengan semakin besarnya ukuran perusahaan maka semakin kecil pula persentase peluang bagi perusahaan untuk melakukan praktik manajemen laba. Ukuran perusahaan dapat dinilai dengan melihat besarnya aset yang dimiliki oleh perusahaan.

\section{Pengaruh Profitabilitas terhadap Manajemen Laba}

Hasil pengujian dari penelitian ini menyatakan bahwa Profitabilitas yang diproksikan dengan Return on Asset (ROA), memiliki pengaruh signifikan positif terhadap manajemen laba. Hasil penelitian ini sejalan dengan penelitian Giovani (2017).

Perusahaan dengan laba yang tinggi akan berusaha untuk mempertahankan labanya pada tingkat tertentu, hal tersebut dilakukan untuk membuat investor percaya dalam berinvestasi. Manajemen akan termotivasi untuk melakukan praktik manajemen laba dengan supaya nantinya laba yang dilaporkan dapat memenuhi target sehingga dapat meningkatkan kepercayaan investor untuk berinvestasi di perusahaan.

\section{Pengaruh Leverage Terhadap Manajemen Laba}

Hasil pengujian pada penelitian ini adalah bahwa leverage yang diproksikan dengan debt to equity tidak berpengaruh signifikan positif terhadap manajemen laba. Penelitian ini sesuai dengan penelitian yang dilakukan oleh Sari (2019). Debt to equity ratio menggambarkan kemampuan perusahaan untuk memenuhi kewajibannya. Dalam penelitian yang dilakukan oleh Sari (2019) dijelaskan bahwa apabila leverage yang diproksikan dengan rasio debt to equity perusahaan mengalami peningkatan, maka peluang terjadinya manajemen laba belum tentu mengalami peningkatan atau penurunan, tingkat terjadinya manajemen laba yang dilakukan oleh pihak manajer akan tetap atau konstan.

\section{SIMPULAN}

Dorongan untuk melakukan manajemen laba dipicu oleh kepemilikan informasi yang tidak setara antara manajer dan pemegang saham sehingga manajer memanfaatkan diskresi akuntansi yang dimiliki untuk mempengaruhi laba perusahaan. Motivasi untuk melakukan manajemen laba bermacam-macam dan salah satunya adalah untuk mendapatkan bonus dan kompensasi keuangan lainnya. Berbagai penelitian telah dilakukan untuk mengidentifikasi faktor-faktor yang mendorong manajaer mempengaruhi laba. Penelitian ini dilakukan untuk memperoleh bukti empiris faktorfaktor yang mempengaruhi manajemen laba dengan menggunakan sampel yang diambil dari perusahaan yang terdaftar di Bursa Efek Indonesia tahun 2015- 2019. Berdasarkan hasil analisis yang telah dilakukan dapat disimpulkan bahwa: 1) Kepemilikan Institusional tidak berpengaruh signifikan terhadap manajemen laba. 2) Kepemilikan Manajerial tidak berpengaruh signifikan terhadap manajemen laba. 3) Ukuran Komite Audit tidak berpengaruh signifikan terhadap manajemen laba. 4) Ukuran Dewan Komisaris tidak berpengaruh signifikan terhadap manajemen laba. 5) Jenis Kepemilikan berpengaruh signifikan positif terhadap manajemen laba. Hasil pengujian juga menunjukkan bahwa dari tiga variabel kontrol yang digunakan ada dua yang berpengaruhi terhadap manajemen laba yaitu ukuran perusahaan dan profitabilitas. Sedangkan leverage tidak berpengaruh signifikan terhadap manajemen laba. 
Jurnal Akuntansi Bisnis, Vol. 19, No. 2, September 2021 ISSN 1412-775X (media cetak) | 2541-5204 (media online)

\section{DAFTAR PUSTAKA}

Boediono, G. 2005. Kualitas Laba: Studi Pengaruh Mekanisme Corporate Governance dan Dampak Manajemen Laba Dengan Menggunakan Analisis Jalur. Corporate Governance, 1516.

Boghdady, A. 2019. The impact of ownership type on the relationship between corporate governance and earnings management: An empirical study. Corporate Ownership and Control, 16(4), 31-44.

Chen, J. J., dan H. Zhang. 2014. The Impact of the Corporate Governance Code on Earnings Management: Evidence from Chinese Listed Companies. European Financial Management, 20(3), 596-632.

Chtourou, S. M., J. Bédard, dan L. Courteau. 2001. Corporate governance and Earnings Management. Corporate Ownership and Control.

Ding, Y., Zhang, H., dan J. Zhang. 2007. Private vs state ownership and earnings management: Evidence from Chinese listed companies. Corporate Governance: An International Review, 15(2), 223-238.

Damayanti, N. P. W. P., dan I. W. Suartana, 2014. Pengaruh Kepemilikan Manajerial Dan Kepemilikan Institusional Pada Nilai Perusahaan. E-Jurnal Akuntansi, 9(3), 575-590.

Fadilla, R. K. 2013. Pengaruh Profitabilitas, Good Corporate Governance dan Kualitas Auditor Eksternal Terhadap Manajemen Laba. Applied Catalysis A: General, 58(2), 15-22.

Fischer, M., dan K. Rosenzweig. 1995. Attitudes of students and accounting practitioners concerning the ethical acceptability of earnings management. Journal of Business Ethics, 14(6), 433-444.

Guna, W. I., dan A. Herawaty. 2010. Pengaruh Mekanisme Good Corporate Governance, Independensi Auditor, Kualitas Audit Dan Faktor Lainnya Terhadap Manajemen Laba. https://jurnaltsm.id/index.php/jba/article/view/162/137

Gunawan, M. G. 2017. Pengaruh Struktur Kepemilikan, Tata Kelola Perusahaan, Dan Karakteristik Perusahaan Terhadap Manajemen Laba. http://repository.unika.ac.id/14933/

Healy, P. M., dan J. M. Wahlen. 1998. A Review of the Earnings Management Literature and Its Implications for Standard Setting. https://www.nature.com/articles/179947d0.pdf

Komite Nasional Kebijakan Governance. 2006. Pedoman Umum Good Corporate Governance Indonesia. Jakarta. http://arikamayanti.lecture.ub.ac.id/files/2015/02/gcg-indonesiabapepam.pdf

Jensen, C., dan H. Meckling. 1976. Theory Of The Firm: Managerial Behavior, Agency Costs And Ownership Structure.

https://josephmahoney.web.illinois.edu/ba549_fall\%202010/session\%205/jensen_meckling $\% 20(1976)$.pdf

Kamardin, H. 2014. Managerial Ownership and Firm Performance: The Influence of Family Directors and Non-family hirectors. $\mathrm{https} / / \mathrm{sci}$ - 
Jurnal Akuntansi Bisnis, Vol. 19, No. 2, September 2021 ISSN 1412-775X (media cetak) | 2541-5204 (media online)

hub.se/https://www.emerald.com/insight/content/doi/10.1108/s2043-

052320140000006002/full/html?skiptracking=true

Karima, N., P. K. Manajerial, K. Institusional, P. Tanggung, dan J. Sosial. 2005. Naila Karima Pengaruh Kepemilikan Manajerial, Kepemilikan Institusional, dan Kepemilikan Asing terhadap Pengungkapan Tanggung Jawab Sosial Perusahaan 219. 219-230. http://repository.widyamandala.ac.id/378/1/06_naila.pdf

Keputusan Ketua Badan Pengawas Pasar Modal dan Lembaga Keuangan (Bapepam) Nomor: Kep643/BL/2012 tentang Pembentukan dan Pedoman Pelaksanaan Kerja Komite Audit. https://www.ojk.go.id/Files/regulasi/pasar-modal/bapepam-pm/emiten-pp/peraturanlain/6.IX.I.5.pdf

Lamora, S., Vince, dan Kamaliah. 2012. Pengaruh Kepemilikan Manajerial, Kepemilikan Institusional Dan Kepemilikan Keluarga Terhadap Manajemen Laba. Journal of Accounting and Economics, 1-15.

Launa, E., dan N. W. Respati. 2017. Pengaruh Mekanisme Corporate Governance Dan Ukuran Perusahaan Terhadap Manajemen Laba. Jurnal Reviu Akuntansi Dan Keuangan, 4(1).

Mahariana, I. G. P., dan I. W. Ramanta. 2014. Pengaruh Kepemilikan Manajerial Dan Kepemilikan Institusional Pada Nilai Perusahaan. E-Jurnal Akuntansi, 9(3), 575-590.

Makhrus, M. 2019. Pengaruh Komite Audit Terhadap Kinerja Perusahaan Melalui Manajemen Laba sebagai Variabel Intervening. Jurnal Akuntansi Dan Keuangan Islam, 1(1), 53-77.

Midiastuty, P. P., dan M. Machfoedz. 2003. Analisis Hubungan Mekanisme Corporate Governance Dan Indikasi Manajemen Laba. 16-17. https://www.academia.edu/31918911/analisis_hubungan_mekanisme_corporate_governanc e_dan_indikasi_manajemen_laba

Naranjo, J. 2014. Bonus Dan Leverage Terhadap Manajemen Lab. Applied Microbiology and Biotechnology, 85(1), 2071-2079. https://doi.org/10.1016/j.bbapap.2013.06.007

Nastiti, R., A. Made, dan E. Dianawati, E. 2016. Analisis Tingkat Discretionary Accrual Sebelum Dan Sesudah Perubahan Tarif Pajak Penghasilan Badan Menurut Uu No 36 Tahun 2008 (Studi Pada Perusahaan Manufaktur Yang Listing Di Bei Tahun 2008 - 2014). Jurnal Riset Mahasiswa Akuntansi Unikama, 4(1), 1-15.

Nasution, M., dan D. Setiawan. 2007. Pengaruh Corporate Governance Terhadap Manajemen Laba Di Industri Perbankan Indonesia. Pengaruh Corporate Governance Terhadap Manajemen Laba Di Industri Perbankan Indonesia. https://datakata.files.wordpress.com/2015/01/akpm05.pdf

Noviardhi, M. T., dan P. B. Hadiprajitno. 2013. Analisis Pengaruh Tata Kelola Perusahaan Terhadap Manajemen Laba. Diponegoro Journal of Accounting, 2(2), 65-73. https://ejournal3.undip.ac.id/index.php/accounting/article/download/3243/3175

Noviyanti, M. 2007. Pengaruh Struktur Kepemilikan, Ukuran Perusahaan,Dan Praktik Corporate Governance Terhadap Manajemen Laba. http://repository.unika.ac.id/13682/

Oktaviani, H. D. 2015. Pengaruh Ukuran Dewan Direksi, Proporsi Dewan Komisaris Independen, 
Jurnal Akuntansi Bisnis, Vol. 19, No. 2, September 2021 ISSN 1412-775X (media cetak) | 2541-5204 (media online)

dan Ukuran Komite Audit terhadap Praktik Manajemen Laba pada Perusahaan Farmasi. PhD Proposal, 1, 1-24. $\quad$ https://jurnalmahasiswa.unesa.ac.id/index.php/jurnalakuntansi/article/download/14728/12888

Permanasari. 2010. Pengaruh Kepemilikan Manajemen, Kepemilikan Institusional, Dan Corporate Social Responsibility Terhadap Nilai Perusahaan. Pengaruh Kepemilikan Manajemen, Kepemilikan Institusional, Dan Corporate Social Responsibility Terhadap Nilai Perusahaan. http://eprints.undip.ac.id/22816/1/wien_ika_permanasari.pdf

Puteri, H. I. 2012. Pengaruh Struktur Kepemilikan, Ukuran Perusahaan, Dan Praktek Corporate Governance Terhadap Manajemen Laba Pada Perusahaan Manufaktur Yang Terdaftar Di Bei. 12(1), 99-127. http://repository.unika.ac.id/10404/

Rachmawati, A., dan H. Triatmoko. 2007. Analisis Faktor-Faktor yang Mempengaruhi Kualitas Laba dan Nilai Perusahaan. Simposium Nasional Akuntansi X Makassar, 1-26. https://datakata.files.wordpress.com/2015/01/akpm-16.pdf

Rustiarini, N. I. W. 2010. Pengaruh Corporate Governance Pada Hubungan CSR dan Nilai Perusahaan. Simposium Nasional Akuntansi XIII, 11, 1-24. https://www.researchgate.net/profile/ni-wayan-

Santoso, A. 2015. Pengaruh Konvergensi IFRS, Struktur Kepemilikan Saham, Tata Kelola Perusahaan, dan Kualitas Audit Terhadap Manajemen Laba. Journal of Chemical Information and Modeling, 53(9), 1689-1699. http://journal.unika.ac.id/index.php/jab/article/view/1346/831

Sari, A. L. 2019. Karakteristik Perusahaan, Tata Kelola Perusahaan Dan Manajemen Laba. Jurnal Akuntansi Bisnis, 15(2), 229. https://doi.org/10.24167/jab.v16i1.1364

Setiawati, L., dan Na'im, A. 2000. Manajemen laba. Jurnal Ekonomi Dan Bisnis Indonesia, 15(4), 424-441.

Sukirai, D. 2012. Kepemilikan Manajerial, Kepemilikan Institusional, Kebijakan Deviden Dan Kebijakan Hutang Analisis Terhadap Nilai Perusahaan. Accounting Analysis Journal, 1(2). https://journal.unnes.ac.id/sju/index.php/aaj/article/view/703/689

Sumanto, B., dan Asrori, K. 2014. Pengaruh Kepemilikan Institusional Dan Ukuran Dewan Komisaris Terhadap Manajemen Laba. Accounting Analysis Journal, 3(1), 44-52. https://journal.unnes.ac.id/sju/index.php/aaj/article/view/3901/3517

Supriadi, Y., dan Gendalasari, G. G. 2018. Pengaruh Laba Terhadap Likuiditas Perusahaan. 1(June), 219-228. https://jurnal.ibik.ac.id/index.php/jimkes/article/download/270/226

The Statement of Financial Accounting Concept (SFAC) No.1. 1978. Financial Accounting Standards Board https://www.fasb.org/jsp/FASB/Document_C/DocumentPage?cid=1218220132541\&accept edDisclaimer=true

Ujiyantho, M. A., dan Agus Pramuka, B. 2007. Mekanisme Corporate Governance, Manajemen Laba dan Kinerja Keuangan (studi pada perusahaan go publik sektor manufaktur). Simposium Nasional Akuntansi X, Juli, 1-26. https://datakata.files.wordpress.com/2015/01/akpm-01.pdf 
Jurnal Akuntansi Bisnis, Vol. 19, No. 2, September 2021 ISSN 1412-775X (media cetak) | 2541-5204 (media online)

Undang-undang No.40 Tahun 2007 tentang Perseroan Terbatas https://www.ojk.go.id/sustainable-finance/id/peraturan/undangundang/Documents/5.\%20UU-40-2007\%20PERSEROAN\%20TERBATAS.pdf

Warfield, T. D., Wild, J. J., dan Wild, K. L. 1995. Managerial ownership, accounting choices, and informativeness of earnings. Journal of Accounting and Economics, 20(1), 61-91. https://www.academia.edu/2563022/managerial_ownership_accounting_choices_and_infor mativeness_of_earnings

Wibowo, L. 2015. Pengaruh Proporsi Dewan Komisaris Independen, Profitabilitas, Kualitas Auditor, Diversifikasi Geografis,Dan Kepemilikan Manajerial Terhadap Manajemen Laba. Procedia - Social and Behavioral Sciences, 2(1), 94. http://repository.unika.ac.id/197/

Widanaputra, A. A. G. P., dan Putri, I. G. A. 2019. Pengaruh Kinerja Lingkungan pada Nilai Perusahaan dengan Good Corporate Governance Sebagai Variabel Pemoderasi. E-Jurnal Akuntansi, 2183. https://doi.org/10.24843/eja.2019.v26.i03.p19

Yermack, D. 1996. Higher Market Valuation for Firms with a Small Board of Directors. Journal of Financial Economics, 40(40), 185-211. http://people.stern.nyu.edu/eofek/phd/papers/y_higher_jfe.pdf 